\title{
Ekstraksi Tannin dari Daun Sirsak (Annona muricata L.) sebagai Pewarna Alami Tekstil
}

\author{
Nana Chintya dan Budi Utami \\ Program Studi Pendidikan Kimia FKIP \\ Universitas Sebelas Maret Surakarta \\ nanachintya37@gmail.com
}

\begin{abstract}
Abstrak
Penelitian ini bertujuan: (1) menentukan rasio kombinasi pelarut etanol 96\%-air yang optimal untuk ekstraksi tannin daun sirsak, (2) menentukan waktu ekstraksi yang optimal untuk ekstraksi tannin daun sirsak, (3) menentukan bahan fiksasi yang tepat agar dihasilkan ketahanan luntur warna yang optimal untuk pewarna alami tannin daun sirsak, dan (4) Menemukan zat pewarna alami dari daun sirsak yang dapat diaplikasikan sebagai pewarna alami tekstil yang berkualitas dan ramah lingkungan.

Penelitian menggunakan metode eksperimen. Daun sirsak dikeringkan, dihaluskan, kemudian disokletasi pada suhu $80^{\circ} \mathrm{C}$ (rasio pelarut etanol-air $=1: 1,1: 2,1: 4$, waktu ekstraksi $=1,2,3$ jam). Analisa kualitatif tannin dengan metode $\mathrm{FeCl}_{3}$. Analisis kuantitatif tannin dengan metode Folin-ciocalteu. Proses pewarnaan kain meliputi mordanting , pewarnaan, fiksasi (dengan tunjung, kapur, tawas). Uji ketahanan luntur warna dengan Laundrymeter dan Crockmeter. Hasil penelitian: (1) rasio kombinasi pelarut etanol 96\%-air yang optimal untuk ekstraksi tannin daun sirsak adalah 1:1, (2) waktu ekstraksi optimal untuk ekstraksi tannin daun sirsak adalah 2 jam, (3) bahan fiksasi yang menghasilkan ketahanan luntur warna yang optimal untuk pewarna alami daun sirsak adalah tawas, dan (4) ekstrak daun sirsak dapat dimanfaatkan sebagai pewarna alami tekstil dengan ketahanan luntur warna yang baik serta ramah lingkungan.
\end{abstract}

Kata-kata kunci: ekstraksi, tannin, daun sirsak, pewarna alami

\begin{abstract}
This research aims to: (1) determine the optimum ratio of ethanol-water for the extraction of tannin from soursop leaves, (2) determine the optimum time for the extraction of tannin from soursop leaves, (3) determine the proper fixation material to produce optimal color fastness of natural dyes tannin from soursop leaves, dan (4) find a natural dye from soursop leaves that can be applied as a natural dye in textiles with high quality and environmentally friendly.

This research used experimental method. Soursop leaf was extracted using soxhletation methods at $80^{\circ} \mathrm{C}$ (rasio of ethanol-water =1:1, 1:2, 1:4, extraction time =1,2, 3 hours). The tannin qualitative test done with $\mathrm{FeCl}_{3}$ method.. The tannin quantitative test done with Folin-Ciocalteu method. Dyeing process included mordanting , coloring, fixation (with Tunjung, chalk, and Tawas). The color fastness was tested with Laundrymeter and Crockmeter. The research concluded that: (1) the optimum ratio of ethanol-water for extraction of tannins from soursop leaves is 1: 1, (2) the optimum time for extraction of tannin from soursop leaves is 2 hours, (3) fixation material that produces optimal color fastness of natural dyes soursop leaves is tawas, dan (4) the soursop leaf extract can be used as natural dyes in textiles that have good color fastness and environmentally friendly.
\end{abstract}

Keywords: extraction, tannins, soursop leaves, natural dye

\section{PENDAHULUAN}

Salah satu andalan Indonesia dalam persaingan di ASEAN adalah industri tekstil. Menurut Ketua Umum Asosiasi Pertekstilan Indonesia Ade Sudrajat Usman (Djumena, 2014) Indonesia merupakan negara pengekspor tekstil terbesar keenam di dunia. Pada tahun 2016, industri tekstil dan produk tekstil (TPT) menempati ranking nomor 3 ekspor nasional

dan mampu memenuhi $70 \%$ kebutuhan sandang dalam negeri (Deny, 2016). Berkembangnya industri tekstil di Indonesia selain memberikan dampak positif terhadap perekonomian bangsa, juga memberikan dampak negatif berupa pencemaran lingkungan. Air limbah hasil industri tekstil dapat dengan mudah dikenal karena warnanya berasal dari 
sisa zat pewarna yang digunakan dalam pewarnaan tekstil. Zat pewarna yang biasa digunakan dalam industri tekstil dibedakan menjadi dua yaitu zat pewarna alami dan zat pewarna sintetis (Fitrihana, 2007). Manurung, dkk. (2004) menyebutkan bahwa industri tekstil biasanya menggunakan zat pewarna sintetis karena mudah diperoleh dan praktis penggunaannya. Namun penggunaan pewarna sintetis dapat berbahaya bagi kesehatan karena dapat menyebabkan kanker kulit, kanker mulut, dan kerusakan otak. Selain itu, penggunaan zat pewarna sintetis dalam industri tekstil telah banyak menimbulkan masalah lingkungan, hal ini dikarenakan zat pewarna sintesik biasanya mengandung senyawa-senyawa non biodegradable dan berbahaya seperti logam-logam berat yaitu $\mathrm{Cu}$, $\mathrm{Ni}, \mathrm{Cr}, \mathrm{Hg}$, dan $\mathrm{Co}$, senyawa aromatik, gugus azo, khlor, dan lain-lain. Kwartiningsih, dkk. (2009) menyebutkan bahwa negara maju seperti Jerman dan Belanda sejak 1 Agustus 1996, melarang penggunaan zat pewarna berbahan kimia sintetik yang didasarkan pada CBI Ref, CBI/NB-3032 tanggal 13 juni 1996 tentang zat pewarna untuk bahan pakaian/clothing, alas kaki/footwear, sprei/bedlinen tidak boleh menggunakan zat warna yang mengandung bahan kimia sintetik, tetapi zat warna yang tidak mempunyai efek samping terhadap lingkungan dan kesehatan yakni zat warna alam. Oleh karena itu, sudah saatnya Indonesia juga mengurangi penggunaan zat warna sintetis untuk tekstil dan digantikan oleh zat warna alam yang aman dan ramah lingkungan.

Mukhlis (2011) menyebutkan bahwa zat pewarna alam selain aman dan ramah lingkungan juga lebih disukai oleh konsumen karena mempunyai warna yang indah dan khas sehingga sulit ditiru oleh zat pewarna sintetis. Kwartiningsih, dkk. (2009) menjelaskan bahwa sebagian besar bahan pewarna alami diambil dari tumbuh-tumbuhan dan merupakan pewarna yang mudah terdegradasi. Bagian-bagian tanaman yang dapat dipergunakan untuk pewarna alami adalah kulit, ranting, batang, daun, akar, biji, bunga, dan getah. Bahan pewarna alami ini meliputi pigmen yang sudah terdapat dalam bahan atau terbentuk pada saat proses pemanasan, penyimpanan, atau pemrosesan. Beberapa pigmen alami yang banyak terdapat di sekitar kita antara lain: klorofil, karotenoid, tannin, dan antosianin. Umumnya, pigmen-pigmen ini bersifat tidak cukup stabil terhadap panas, cahaya, dan $\mathrm{pH}$ tertentu.

Salah satu tanaman yang dapat dimanfaatkan sebagai pewarna alami adalah tanaman sirsak. Tanaman sirsak (Annona muricata Linn) merupakan tumbuhan berbuah yang banyak dijumpai di Indonesia. Selain rasa buahnya yang banyak disukai, daun sirsak juga dipercaya sebagai obat tradisional oleh masyarakat Indonesia. Selain sebagai obat tradisional, daun sirsak jarang sekali dimanfaatkan untuk penelitian. Berdasarkan penelitian skrining fitokimia ekstrak daun sirsak yang telah dilakukan oleh Wisdom, et al. (2014), diketahui bahwa daun sirsak mengandung tannin. Oleh karena itu daun sirsak dapat digunakan untuk bahan dasar pewarna alami tekstil yang ramah lingkungan. Berdasarkan penelitian yang telah dilakukan oleh Lestari, dkk. (2014); Mukhlis (2011); dan Rosyida \& Zulfiya (2013) zat pewarna alami tannin akan menghasilkan warna kuning hingga coklat tua pada kain.

Pengambilan tannin dari daun sirsak dilakukan dengan cara ekstraksi. Proses ekstraksi dipengaruhi oleh suhu, ukuran partikel, jenis pelarut, dan waktu ekstraksi. Pemilihan metode ekstraksi dapat mempengaruhi hasil ekstrak senyawa fenol. Dalam penelitian ini digunakan metode sokletasi, yaitu suatu metode dengan pemanasan, dimana pelarut yang digunakan akan mengalami sirkulasi dan secara kontinyu mengekstrak tanin dalam daun sirsak. Dibandingkan dengan cara maserasi, hasil ekstraksi sokletasi memberikan hasil lebih tinggi (Irianty \& Verawati, 2012).

Deny (2007) menyebutkan bahwa tannin dapat diekstrak dengan beberapa pelarut. Pelarut yang umum digunakan adalah air, aseton, etanol, dan metanol. Secara komersial tannin dapat diekstraksi dengan pelarut air tetapi yang paling efektif untuk mengekstrak tannin adalah campuran air dengan etanol. Dalam penelitian ini peneliti menggunakan pelarut campuran etanol $96 \%$ dan air. Rasio kombinasi pelarut etanol dan air untuk mengekstraksi tannin dari daun sirsak dapat mempengaruhi konsentrasi tannin yang dihasilkan. Lestari, dkk. (2014) menjelaskan bahwa ekstraksi tannin akan optimal jika pelarut yang digunakan memiliki tingkat kepolaran yang sama dengan senyawa tannin yang diekstrak. Oleh karena itu perlu dicari rasio kombinasi etanol dan air yang tepat untuk mengekstraksi tannin dari daun sirsak.

Faktor waktu ekstraksi juga merupakan hal yang cukup penting karena dapat mempengaruhi kualitas hasil ekstraksi. Proses ekstraksi yang terlalu lama akan mengakibatkan rusaknya kandungan tannin, sedangkan proses ekstraksi yang terlalu singkat akan menghasilkan kandungan tannin yang kurang optimal (Lestari, dkk., 2014). Oleh karena itu perlu dicari waktu ekstraksi yang optimal untuk mengekstraksi tannin dari daun sirsak.

Pada penelitian ini, pewarna alami tannin dari daun sirsak yang diperoleh melalui proses ekstraksi akan dicobakan pada kain katun jenis prima untuk 
mengetahui kualitas zat warna yang dihasilkan. Kelemahan dari pewarna alami dibandingkan pewarna sintetis adalah ketahanan lunturnya yang lebih rendah. Untuk memperoleh ketahanan luntur yang tinggi perlu dilakukan proses fiksasi (pembangkitan warna) yang bertujuan untuk mempertajam warna dan supaya tidak mudah luntur (Kasmudjo, dkk., 2011). Bahan fiksasi yang biasa digunakan untuk pewarnaan tekstil dengan bahan alam adalah tunjung, tawas, dan kapur. Pemilihan bahan fiksasi sangat penting dalam pewarnaan tekstil karena akan mempengaruhi nilai ketahanan luntur dari pewarna itu sendiri. Oleh karena itu perlu dicari bahan fiksasi yang tepat untuk menghasilkan ketahanan luntur warna paling optimal dari pewarna alami tannin daun sirsak.

Dari uraian di atas, dapat disimpulkan bahwa perlu dilakukan penelitian untuk menemukan rasio kombinasi pelarut etanol dan air, waktu ekstraksi, serta bahan fiksasi yang tepat untuk pewarna alami tannin dari daun sirsak, sehingga dapat dihasilkan pewarna alami tekstil dari tannin daun sirsak yang berkualitas dan ramah lingkungan.

\section{METODE}

\section{Proses Ekstraksi Sokletasi Daun Sirsak}

Daun sirsak diangin-anginkan sampai kering $( \pm 4$ minggu), kemudian dipisahkan dari ibu tulang daunnya dan diblender sampai halus. Bubuk daun sirsak kemudian dioven pada suhu $60^{\circ} \mathrm{C}$ selama 6 jam. Pada proses sokletasi, sebanyak $5 \mathrm{~g}$ bubuk daun sirsak diekstraksi sokletasi dengan $150 \mathrm{~mL}$ pelarut yang terdiri dari campuran etanol $96 \%$ dan air. Variasi rasio etanol-air adalah 1:1, 1:2, dan 1:4, sedangkan variasi waktu ekstraksi adalah 1 jam, 2 jam, dan 3 jam.

\section{Uji Kualitatif dan Kuantitatif Tannin}

\section{Preparasi Sampel Uji (Pembuatan Larutan Uji 1000 ppm)}

Hasil ekstraksi daun sirsak (sebanyak 9 sampel) disaring dengan kertas saring, pelarutnya dipisahkan menggunakan rotary evaporator pada suhu $80^{\circ} \mathrm{C}$ selama 20 menit, ekstrak dikeringkan dengan oven selama 30 menit pada suhu $100^{\circ} \mathrm{C}$. Sebanyak $0,1 \mathrm{~g}$ ekstrak dari masing-masing sampel dilarutkan dalam akuades sampai volume menjadi $100 \mathrm{~mL}$ sehingga dihasilkan larutan konsentrasi 1000 ppm.

\section{Uji Kualitatif Tannin}

Pengujian kualitatif tannin dilakukan dengan metode Besi(III) klorida $\left(\mathrm{FeCl}_{3}\right)$. Uji positif adanya tannin ditandai dengan terbentuknya warna biru kehitaman/hijau kehitaman yang mengindikasikan adanya tannin dalam larutan uji (Irianty \& Verawati, 2012).

Ke dalam suatu plat tetes, dimasukkan masingmasing 3 tetes larutan ekstrak 1000 ppm (total ada 9 larutan), setelah itu ditambah 3 tetes larutan $\mathrm{FeCl}_{3}$ $1 \%$ dan diamati perubahan warna yang terjadi.

\section{Uji Kuantitatif Tannin}

Pengujian kuantitatif tanin dilakukan dengan metode analisis fenolik yaitu metode Folin-ciocalteu yang selanjutnya dianalisa dengan spektrofotometer UV-Vis pada panjang gelombang maksimum $(747,5$ nm). Pertama-tama, membuat kurva standar larutan asam tanat. Sebanyak $0,5 \mathrm{~mL}$ larutan standar asam tanat dari masing-masing konsentrasi $(50,100,150$, 200, 250, dan $300 \mathrm{ppm}$ ) ditambah dengan akuades $7,5 \mathrm{~mL}$, selanjutnya dicampur dengan $0,5 \mathrm{~mL}$ reagen Folin-ciocalteu (dibiarkan \pm 5 menit) kemudian ditambah dengan $\mathrm{Na}_{2} \mathrm{CO}_{3} 20 \%$ (b/v) sebanyak 1,5 $\mathrm{mL}$ dan diletakkan di tempat yang tidak terkena cahaya 30 menit untuk proses homogenisasi. Selanjutnya, dilakukan pengukuran absorbansi dengan spektrofotometer UV-Vis pada pada panjang gelombang maksimum. Hasil pembacaan absorbansi dibuat kurva dan persamaan regresinya. Selanjutnya, adalah mengukur absorbansi sampel. Sampel ekstrak daun sirsak 1000 ppm (sebanyak 9 sampel) dilakukan langkah yang sama seperti pada larutan standar. Hasil pembacaan absorbansi sampel kemudian dimasukkan pada persamaan regresi untuk mengetahui kadar tanin dari sampel (ekstrak daun sirsak). Dari hasil perhitungan kadar tannin dalam sampel, dapat diketahui rasio kombinasi pelarut etanol 96\% dan air dan waktu ektraksi yang paling optimal untuk ekstraksi tannin dari daun sirsak.

\section{Proses Pewarnaan Kain}

\section{Proses Mordanting}

Kain katun prima warna putih dipotong dengan ukuran 100x10 cm sebanyak 5 lembar, kain kemudian direndam dalam $1 \mathrm{~L}$ larutan teepol $2 \%$. Setelah itu, membuat larutan yang mengandung 50 gram tawas $\left(\mathrm{KAl}\left(\mathrm{SO}_{4}\right)_{2} \cdot 12 \mathrm{H}_{2} \mathrm{O}\right)$ dan 20 gam soda abu $\left(\mathrm{Na}_{2} \mathrm{CO}_{3}\right)$ dalam $1000 \mathrm{~mL}$ air, kemudian merendam kain dalam larutan hangat tersebut selama 20 menit. Setelah 20 menit, kain diangkat, dibilas, kemudian dikeringkan dan disetrika.

\section{Proses Pewarnaan}

Ekstrak 5 g bubuk daun sirsak dalam $150 \mathrm{~mL}$ pelarut (etanol 96\%:air = 1:1) dan waktu ekstraksi disesuaikan dengan hasil penelitian ekstraksi yang optimum, ekstraksi sokletasi ini diulang sebanyak 10 kali sehingga didapat ekstrak 1L. 
Pewarnaan dilakukan dengan merebus 4 kain dalam $1 \mathrm{~L}$ zat warna selama 1 jam. Setelah itu, mengangkat kain dari larutan zat warna dan dianginanginkan sampai kering.

\section{Proses Fiksasi}

Sebanyak masing-masing $25 \mathrm{~g}$ tawas, kapur, dan tunjung di larutkan dalam $500 \mathrm{~mL}$ air, dibiarkan mengendap, kemudian diambil larutan bening (filtrat) sebagai larutan fikser. Tiga kain yang telah diwarnai masing-masing direndam dalam larutan tawas $\left(\mathrm{KAl}\left(\mathrm{SO}_{4}\right)_{2} \cdot 12 \mathrm{H}_{2} \mathrm{O}\right)$ dan kapur tohor $\left(\mathrm{CaCO}_{3}\right)$, dan $\mathrm{FeSO}_{4}$ selama 15 menit. Setelah itu, kain diangkat, dikeringkan, kain kemudian dicuci, dikeringkan kembali, dan disetrika.

\section{Pengujian Ketahanan Luntur Zat Warna}

Kain yang telah diwarnai dan difiksasi diuji tahan luntur warnanya dengan alat Laundrymeter dan Crockmeter. Penilaian dilakukan dengan membandingkan perubahan warna yang terjadi dengan standar perubahan warna yaitu Grey scale dan Staining scale.

Tabel 1. Penilaian Perubahan Warna pada Grey Scale dan Stanning

\begin{tabular}{|c|c|c|c|}
\hline $\begin{array}{l}\text { Nilai } \\
\text { Tahan } \\
\text { Luntur } \\
\text { Warne }\end{array}$ & $\begin{array}{c}\text { Perbedaan } \\
\text { warna } \\
\text { (dalam } \\
\text { suatu CD) } \\
\text { Gray scale }\end{array}$ & $\begin{array}{c}\text { Perbedaan } \\
\text { warna } \\
\text { (dalam suatu } \\
\text { CD) } \\
\text { Stelningscale }\end{array}$ & $\begin{array}{l}\text { Hasil } \\
\text { Evaluasi } \\
\text { Tahan } \\
\text { Luntur } \\
\text { Warna }\end{array}$ \\
\hline $1-5$ & $\begin{array}{c}0 \\
0.8\end{array}$ & $\begin{array}{l}0.0 \\
2,0\end{array}$ & $\begin{array}{c}\text { Daik Sykdi } \\
\text { Brik }\end{array}$ \\
\hline 4 & $1 \mathrm{~s}$ & 40 & 13.ak \\
\hline $3-4$ & 21 & $56 i$ & Cukun Hakk \\
\hline $2^{3} 3$ & $\begin{array}{l}3.0 \\
4.2\end{array}$ & 0.0 & $\begin{array}{l}\text { Cukup } \\
\text { Kurany }\end{array}$ \\
\hline 3 & 60 & 160 & Kurang \\
\hline $1-2$ & 0,5 & 22.6 & Jelek. \\
\hline 1 & 120 & 326 & Ieick \\
\hline
\end{tabular}

Sumber: Sunarto, (2008: 399-403)

\section{HASIL DAN PEMBAHASAN}

\section{Proses Ekstraksi Sokletasi Daun Sirsak}

Daun sirsak yang semula berwarna hijau sebanyak 250 g setelah dikeringkan, dihaluskan, dan dioven berubah menjadi bubuk hijau kecoklatan dengan massa 120 g. Dari proses ekstraksi sokletasi dihasilkan 9 sampel dengan filtrat berwarna coklat kehijauan.

\section{Uji Kualitatif dan Kuantitatif Tannin}

\section{Uji Kualitatif Tannin}

Setelah ditambah $\mathrm{FeCl}_{3}$ larutan yang semula kuning muda berubah menjadi hijau. Perubahan warna menjadi hijau menunjukkan hasil positif adanya tannin dalam ekstrak daun sirsak. Terbentuknya warna hijau disebabkan oleh reaksi tannin dan $\mathrm{Fe}^{3+}$ yang membentuk senyawa kompleks (Kusumaningsih, dkk., 2015).

\section{Uji Kuantitatif Tannin}

Penentuan Panjang Gelombang Maksimum dengan Spektrofotometer UV-Vis

Dari hasil pengukuran, didapatkan panjang gelombang maksimum sebesar $734 \mathrm{~nm}$. Hasil ini sesuai dengan pendapat Apsari \& Susanti (2011) yang menyebutkan bahwa panjang gelombang maksimum dari tannin berada pada 600-850 nm

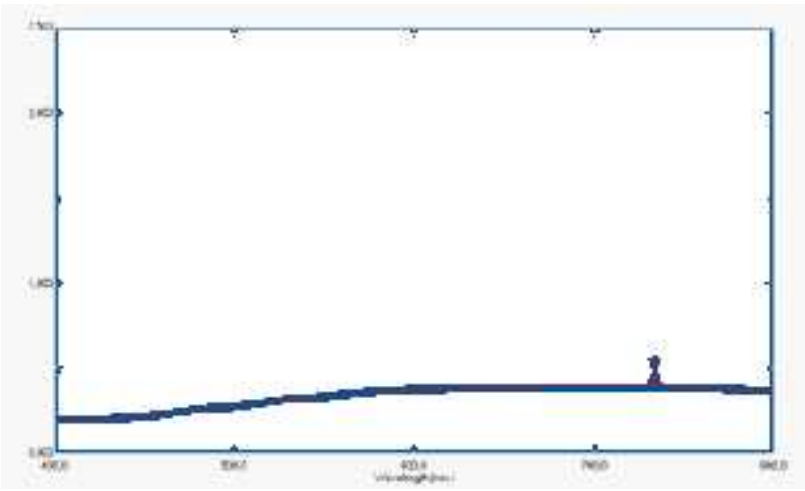

Gambar 2. Kurva Hasil Pengukuran Panjang Gelombang Maksimum

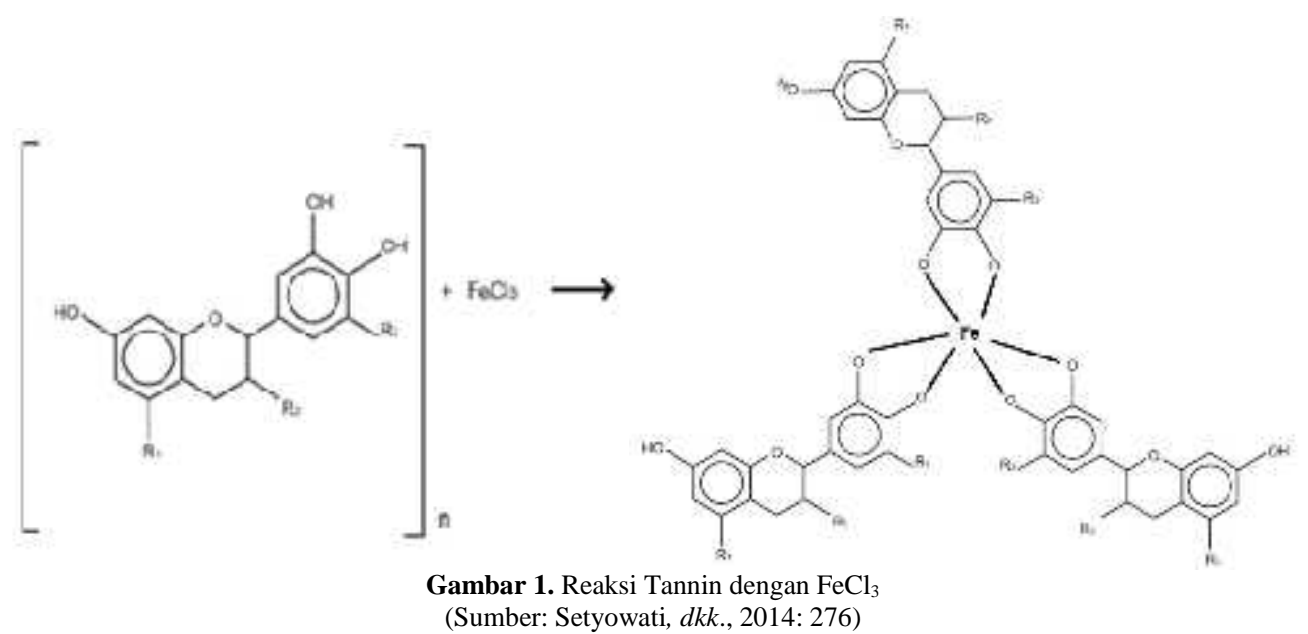


Pembuatan Kurva Kalibrasi Larutan Standar Asam Tanat

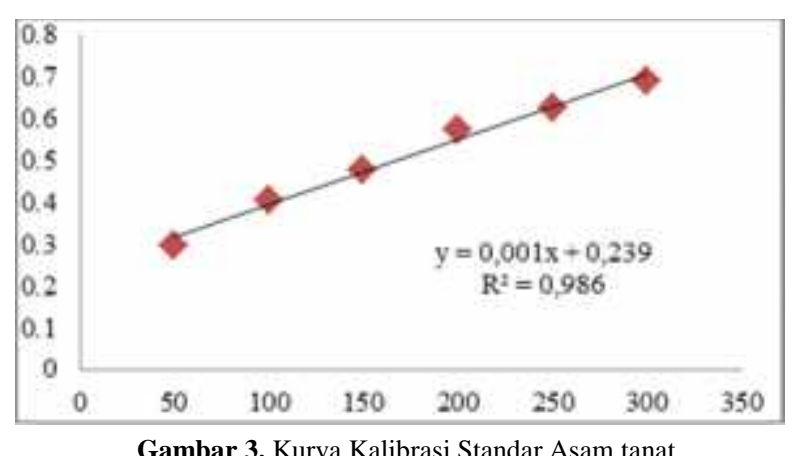

Dari kurva standar asam tanat diperoleh persamaan $\mathrm{y}=0,001 \mathrm{x}+0,239$

\section{Hasil Perhitungan Kadar Tannin dalam Sampel}

Dari hasil perhitungan didapatkan kadar tannin terbesar terletak pada sampel dengan rasio kombinasi pelarut etanol 96\% dan air 1:1 dan waktu ekstraksi 2 jam yaitu sebesar 281 ppm dalam 1000 ppm ekstrak daun sirsak. Hasil ini menunjukkan bahwa rasio pelarut etanol-air 1:1 merupakan rasio dengan kepolaran yang sesuai untuk ekstraksi tannin dari daun sirsak. Menurut Lestari, dkk. (2014), pelarut yang memiliki tingkat kepolaran yang sama dengan senyawa yang diekstrak akan memberikan hasil yang lebih maksimal. Berdasarkan hasil penelitian, pelarut etanol-air dengan rasio 1:1 diduga memiliki sifat kepolaran yang sama dengan tannin dari daun sirsak sehingga hasil ekstraksinya maksimal. Selain itu, menurut Parasetia, dkk. (2012) kadar air yang tinggi menyebabkan hasil ekstraksi sokletasi menjadi kurang optimal, hal ini dikarenakan titik didih air yang tinggi membutuhkan lebih banyak waktu untuk menguapkan air dalam ekstraksi, sehingga pada waktu yang sama dengan kadar air lebih tinggi akan menghasilkan yield lebih sedikit.

Waktu ekstraksi juga terlihat berpengaruh dalam hasil konsentrasi tannin. Pada waktu ekstraksi 1 jam konsentrasi tannin cukup rendah kemudian konsentrasi tannin naik ketika waktu ekstraksi 2 jam dan kembali turun pada waktu ekstraksi 3 jam. Hal ini sesuai dengan penelitian Lestari, dkk. (2014) yang menyebutkan bahwa waktu ekstraksi pada setiap bahan mempunyai batas optimum, dimana penambahan waktu melampaui batas optimumnya menjadi tidak berpengaruh, hal ini karena dimungkinkan senyawa yang sudah berpindah ke pelarut akan mengalami dekomposisi karena pemanasan yang terus menerus. Dengan kata lain waktu ekstraksi yang semakin lama akan menghasilkan tannin yang terekstrak lebih banyak, sampai titik optimumnya.
Tabel 2. Hasil Perhitungan Konsentrasi Tannin Ekstrak Daun Sirsak

\begin{tabular}{ccccc}
\hline No & $\begin{array}{c}\text { Rasio } \\
\text { Etanol : Air }\end{array}$ & $\begin{array}{c}\text { Waktu } \\
\text { (jam) }\end{array}$ & A & $\begin{array}{c}\text { Kadar Tannin (per } \\
\text { 1000 ppm ekstrak) }\end{array}$ \\
\hline 1. & $1: 1$ & 1 jam & 0,5125 & 273,5 ppm \\
2. & $1: 1$ & 2 jam & 0,5200 & 281,0 ppm \\
3. & $1: 1$ & 3 jam & 0,4895 & $250,5 \mathrm{ppm}$ \\
4. & $1: 2$ & 1 jam & 0,4655 & $226,5 \mathrm{ppm}$ \\
5. & $1: 2$ & 2 Jam & 0,4830 & $244,0 \mathrm{ppm}$ \\
6. & $1: 2$ & 3 jam & 0,4595 & $220,5 \mathrm{ppm}$ \\
7. & $1: 4$ & 1 jam & 0,4280 & $189,0 \mathrm{ppm}$ \\
8. & $1: 4$ & 2 jam & 0,4540 & $215,0 \mathrm{ppm}$ \\
9. & $1: 4$ & 3 jam & 0,4415 & $202,5 \mathrm{ppm}$ \\
\hline
\end{tabular}

\section{Proses Pewarnaan Kain}

\section{Proses Mordanting}

Proses mordanting pada prinsipnya dilakukan dengan merendam kain kedalam garam-garam logam, seperti aluminium, besi, timah atau krom pada kain katun berwarna putih. Pada penelitian ini digunakan tawas sebagai zat mordant. Zat-zat mordan ini berfungsi untuk membentuk ikatan antara zat warna alam dengan serat sehingga afinitas zat warna meningkat terhadap serat (Mukhlis, 2011).

\section{Proses Pewarnaan}

Larutan zat warna tannin yang dihasilkan berwarna cokelat. Setelah proses pencelupan dengan pewarna alami tanin dari daun sirsak, warna kain katun yang semula putih berubah menjadi kuning kecoklatan.

\section{Proses Fiksasi}

Larutan fikser tawas tak berwarna, larutan kapur berwarna putih keruh, sedangkan larutan fikser tunjung berwarna jingga. Setelah difiksasi, kain katun yang semula berwarna kuning mengalami perubahan warna. Fiksasi tawas menghasilkan warna cokelat muda, fiksasi kapur menghasilkan warna cokelat, sedangkan fiksasi tunjung menghasilkan warna cokelat kehijauan.

Perubahan warna yang terjadi setelah proses fiksasi dikarenakan adanya reaksi antara tannin dengan logam $\mathrm{Fe}^{2+}, \mathrm{Ca}^{2+}, \mathrm{Al}^{3+}$ dari bahan fiksasi yang menghasilkan garam kompleks. Proses fiksasi menyebabkan molekul zat warna menjadi lebih besar dengan membentuk garam kompleks, hal ini menyebabkan zat warna tersebut tidak dapat keluar dari serat, sehingga ketahanan lunturnya meningkat (Prayitno, dkk., 2014).

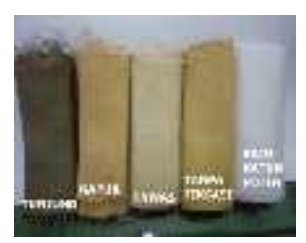

Gambar 5. Gambar Hasil Fiksasi (Tunjung, Kapur, Tawas, Tanpa Fiksasi, Kain putih) 


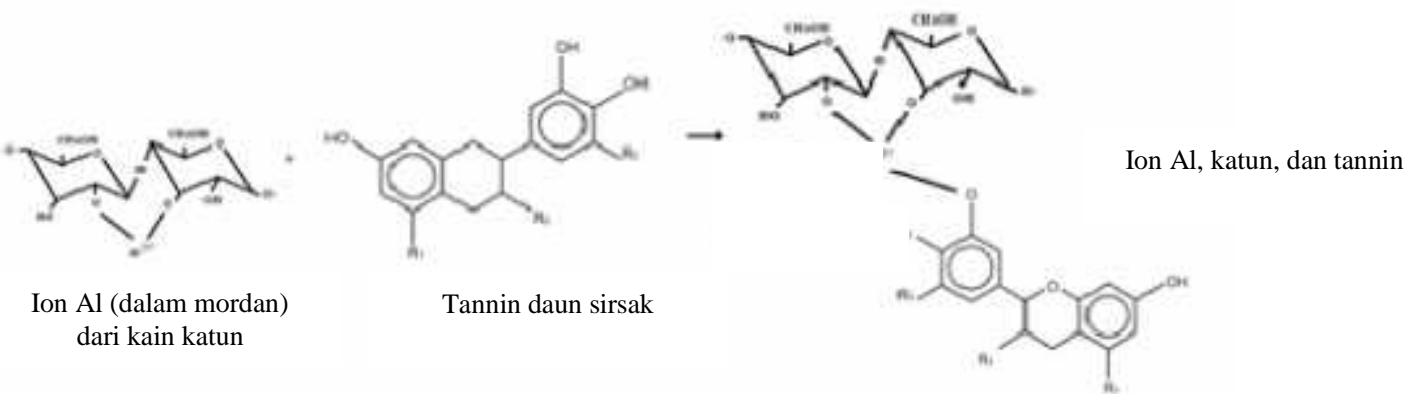

Gambar 4. Reaksi antara Zat Mordan, Sellulosa Pada Kain, dan Tannin Daun Sirsak (Sumber: Wilujeng, Kusnawati, \& Pratiwi, 2010: 8)

Pengujian Ketahanan Luntur Zat Warna

Tabel 3. Hasil Ketahanan Luntur Warna terhadap Pencucian dengan Laundrymeter

\begin{tabular}{|c|c|c|c|c|c|c|c|c|c|c|c|c|c|c|c|c|}
\hline \multicolumn{9}{|c|}{ Nilai Gay Scale } & \multicolumn{8}{|c|}{ Nilai Stainning Scale } \\
\hline \multirow[t]{2}{*}{ No } & \multicolumn{2}{|c|}{$\begin{array}{c}\text { Tanpa } \\
\text { Fiksasi }\end{array}$} & \multicolumn{2}{|c|}{$\begin{array}{c}\text { Fiksasi } \\
\text { Tunjung }\end{array}$} & \multicolumn{2}{|c|}{$\begin{array}{c}\text { Fiksasi } \\
\text { Tawas }\end{array}$} & \multicolumn{2}{|c|}{$\begin{array}{c}\text { Fiksasi } \\
\text { Kapur }\end{array}$} & \multicolumn{2}{|c|}{$\begin{array}{c}\text { Tanpa } \\
\text { Fiksasi }\end{array}$} & \multicolumn{2}{|c|}{$\begin{array}{l}\text { Fiksasi } \\
\text { Tunjung }\end{array}$} & \multicolumn{2}{|c|}{$\begin{array}{c}\text { Fiksasi } \\
\text { Tawas }\end{array}$} & \multicolumn{2}{|c|}{$\begin{array}{c}\text { Fiksasi } \\
\text { Kapur }\end{array}$} \\
\hline & GS & $\mathrm{CD}$ & GS & $\mathrm{CD}$ & GS & $\mathrm{CD}$ & GS & $\mathrm{CD}$ & SS & $\mathrm{CD}$ & SS & $\mathrm{CD}$ & SS & $\mathrm{CD}$ & SS & $\mathrm{CD}$ \\
\hline 1 & $1-2$ & 8,5 & $2-3$ & 4,2 & 3 & 3 & $2-3$ & 4,2 & $3-4$ & 5,6 & $4-5$ & 2 & $4-5$ & 2 & 4 & 4 \\
\hline 2 & $1-2$ & 8,5 & $2-3$ & 4,2 & 3 & 3 & $2-3$ & 4,2 & $3-4$ & 5,6 & $4-5$ & 2 & 4 & 4 & 4 & 4 \\
\hline 3 & $1-2$ & 8,5 & $2-3$ & 4,2 & 3 & 3 & $2-3$ & 4,2 & $3-4$ & 5,6 & $4-5$ & 2 & $4-5$ & 2 & 4 & 4 \\
\hline Rata-rata CD & \multicolumn{2}{|c|}{8,5} & \multicolumn{2}{|c|}{4,2} & \multicolumn{2}{|c|}{3} & \multicolumn{2}{|c|}{4,2} & \multicolumn{2}{|c|}{5,6} & \multicolumn{2}{|c|}{2} & \multicolumn{2}{|c|}{2,67} & \multicolumn{2}{|c|}{4} \\
\hline $\begin{array}{l}\text { GS dan SS } \\
\text { akhir }\end{array}$ & \multicolumn{2}{|c|}{$1-2$} & \multicolumn{2}{|c|}{$2-3$} & \multicolumn{2}{|c|}{3} & \multicolumn{2}{|c|}{$2-3$} & \multicolumn{2}{|c|}{$3-4$} & \multicolumn{2}{|c|}{$4-5$} & \multicolumn{2}{|c|}{$4-5$} & \multicolumn{2}{|c|}{4} \\
\hline Evaluasi & \multicolumn{2}{|c|}{ Jelek } & \multicolumn{2}{|c|}{ Kurang } & \multicolumn{2}{|c|}{ Cukup } & \multicolumn{2}{|c|}{ Kurang } & $\begin{array}{c}\mathrm{Cu} \\
\mathrm{B}\end{array}$ & & \multicolumn{2}{|c|}{ Baik } & \multicolumn{2}{|c|}{ Baik } & \multicolumn{2}{|c|}{ Baik } \\
\hline
\end{tabular}

Tabel 4. Hasil Ketahanan Luntur Warna terhadap Gosokan dengan Crockmeter

\begin{tabular}{|c|c|c|c|c|c|c|c|c|c|c|c|c|c|c|c|c|}
\hline \multicolumn{9}{|c|}{ Gosokan Basah } & \multicolumn{8}{|c|}{ Gosokan Kering } \\
\hline \multirow[t]{2}{*}{ No } & \multicolumn{2}{|c|}{$\begin{array}{c}\text { Tanpa } \\
\text { Fiksasi }\end{array}$} & \multicolumn{2}{|c|}{$\begin{array}{c}\text { Fiksasi } \\
\text { Tunjung }\end{array}$} & \multicolumn{2}{|c|}{$\begin{array}{c}\text { Fiksasi } \\
\text { Tawas }\end{array}$} & \multicolumn{2}{|c|}{$\begin{array}{c}\text { Fiksasi } \\
\text { Kapur }\end{array}$} & \multicolumn{2}{|c|}{$\begin{array}{c}\text { Tanpa } \\
\text { Fiksasi }\end{array}$} & \multicolumn{2}{|c|}{$\begin{array}{l}\text { Fiksasi } \\
\text { Tunjung }\end{array}$} & \multicolumn{2}{|c|}{$\begin{array}{c}\text { Fiksasi } \\
\text { Tawas }\end{array}$} & \multicolumn{2}{|c|}{$\begin{array}{c}\text { Fiksasi } \\
\text { Kapur }\end{array}$} \\
\hline & SS & $\mathrm{CD}$ & SS & $\mathrm{CD}$ & SS & $\mathrm{CD}$ & SS & $\mathrm{CD}$ & SS & $\mathrm{CD}$ & SS & $\mathrm{CD}$ & SS & $\mathrm{CD}$ & SS & $\mathrm{CD}$ \\
\hline 1 & $1-2$ & 22,6 & $2-3$ & 11,3 & 3 & 8 & 3 & 8 & 3 & 8 & $4-5$ & 2 & $4-5$ & 2 & $4-5$ & 2 \\
\hline 2 & 2 & 16 & $2-3$ & 11,3 & $4-5$ & 2 & 3 & 8 & $2-3$ & 11,3 & 3 & 8 & $4-5$ & 2 & 4 & 4 \\
\hline 3 & $1-2$ & 22,6 & 2 & 16 & 3 & 8 & 3 & 4 & $2-3$ & 11,3 & $3-4$ & 5,6 & 4 & 4 & 4 & 4 \\
\hline Rata-rata CD & \multicolumn{2}{|c|}{20,4} & \multicolumn{2}{|c|}{12,86} & \multicolumn{2}{|c|}{6} & \multicolumn{2}{|c|}{6,67} & \multicolumn{2}{|c|}{10,2} & \multicolumn{2}{|c|}{5,2} & \multicolumn{2}{|c|}{2,66} & \multicolumn{2}{|c|}{3,33} \\
\hline SS akhir & \multicolumn{2}{|c|}{$1-2$} & \multicolumn{2}{|c|}{$2-3$} & \multicolumn{2}{|c|}{$3-4$} & \multicolumn{2}{|c|}{$3-4$} & \multicolumn{2}{|c|}{$2-3$} & \multicolumn{2}{|c|}{$3-4$} & \multicolumn{2}{|c|}{$4-5$} & \multicolumn{2}{|c|}{4} \\
\hline Evaluasi & \multicolumn{2}{|c|}{ Jelek } & \multicolumn{2}{|c|}{ Kurang } & \multicolumn{2}{|c|}{$\begin{array}{l}\text { Cukup } \\
\text { Baik }\end{array}$} & \multicolumn{2}{|c|}{$\begin{array}{c}\text { Cukup } \\
\text { Baik }\end{array}$} & \multicolumn{2}{|c|}{ Kurang } & \multicolumn{2}{|c|}{ Cukup Baik } & \multicolumn{2}{|c|}{ Baik } & \multicolumn{2}{|c|}{ Baik } \\
\hline
\end{tabular}

Pada uji pencucian, bahan tekstil direndam dalam larutan sabun dan dikenai gerakan-gerakan mekanik. Warna pada bahan tekstil diserang oleh zat kimia dan gerak mekanik. Sedangkan pada uji gosokan, bahan tekstil hanya dikenai gerakan-gerakan mekanik. Apabila ikatan antara zat pewarna dan serat kuat, warna pada kain tidak akan luntur (Kasmudjo, dkk., 2011). Dari penelitian menunjukkan bahwa dengan fiksasi nilai katahanan luntur warna meningkat. Ketahanan luntur zat warna terhadap gosokan basah mempunyai nilai yang lebih rendah dibandingkan dengan gosokan kering. Hal ini dikarenakan jika serat kain terkena air akan menyebabkan penggembungan pada serat sehingga molekul zat warna akan mudah keluar saat penggosokan sehingga ketahanan lunturnya lebih rendah (Prayitno, dkk., 2014). Jika dievaluasi secara deskriptif, rerata ketahanan luntur warna dengan fiksasi secara keseluruhan sudah baik. Hal ini sesuai dengan pendapat Prayitno, dkk. (2014) yang menyatakan bahwa hasil penguncian warna (fiksasi) ketahanan lunturnya minimal cukup dengan nilai $\mathrm{CD}$ sebesar 3.00 .

Bahan fiksasi yang menunjukkan nilai ketahanan luntur warna terbaik terhadap uji pencucian maupun uji gosokan adalah tawas. Pada uji pencucian nilai GS akhir 3 (cukup) dan SS akhir 4-5 (baik). Pada uji gosokan nilai SS akhir gosokan basah 3-4 (cukup baik) dan SS akhir gosokan kering 4-5 (baik).

Ketahanan luntur zat warna dipengaruhi oleh kestabilan senyawa kompleks yang terbentuk saat proses fiksasi. Ketahanan luntur fiksasi tawas memberikan nilai terbaik mungkin disebabkan oleh kuatnya ikatan pada kompleks tawas-tannin. Menurut Saputro (2012), kestabilan senyawa kompleks dipengaruhi oleh beberapa hal, tiga diantaranya adalah ligan, potensi ionik atom pusat, dan kekuatan ikatan. Karena ligan yang terdapat dalam penelitian ini sama, yaitu tannin, maka kestabilan senyawa kompleks dapat diasumsikan hanya dipengaruhi oleh potensi ionik atom pusat dan 
kekuatan ikatan. Semakin kecil jari-jari dan semakin besar muatan ion logam, atau semakin besar muatan dibagi jari-jarinya maka potensi ionik atom pusat dan kekuatan ikatan antara ion logam dan tannin makin besar, sehingga semakin stabil senyawa kompleks yang terbentuk (Saputro, 2012).

Pada pembentukan kompleks tanin-fikser, Ion pusat tannin-tunjung adalah $\mathrm{Fe}^{2+}$, ion pusat tannintawas adalah $\mathrm{Al}^{3+}$, sedangkan ion pusat pada tanninkapur adalah $\mathrm{Ca}^{2+}$.

Dari perhitungan Tabel 5, dapat disimpulkan bahwa potensi ionik atom pusat pada tawas paling besar dibandingkan dengan tunjung dan kapur. Hal ini menyebabkan kekuatan ikatan pada kompleks tannin-tawas lebih kuat dan senyawa kompleks yang dihasilkan lebih stabil. Semakin stabil kompleks semakin sulit kompleks tersebut terdekomposisi sehingga semakin baik ketahanan lunturnya.

Tabel 5. Perhitungan Potensi Ionik Atom Pusat

\begin{tabular}{lccc}
\hline & Tunjung & Tawas & Kapur \\
\hline Atom Pusat & $\mathrm{Fe}^{2+}$ & $\mathrm{Al}^{3+}$ & $\mathrm{Ca}^{2+}$ \\
Muatan atom pusat & $2+$ & $3+$ & $2+$ \\
Jari-jari ion atom pusat $(\AA)$ & 0,83 & 0,50 & 0,99 \\
$\frac{\text { Muaton }}{\text { Iarn - jur }}$ & 2,41 & 6 & 2,02 \\
\hline Sumber: Saputro (2012: 149) & & &
\end{tabular}

\section{DAFTAR PUSTAKA}

Apsari, P.D. \& Susanti, H. 2011. Perbandingan Kadar Fenolik Total Ekstrak Metanol Kelopak Merah dan Ungu Bunga Rosella (Hibiscus sabdariffa Linn) secara Spektrofotometri. Prosiding Seminar Nasional "Home Care", hlm. 73-77, Universitas Ahmad Dahlan, Yogyakarta.

Deny. 2007. Pemanfaatan Tanin sebagai Perekat. Jurnal Penelitian Fakultas Teknologi Pertanian Bogor, 1-2.

Deny, S. 2016. Industri Tekstil Ditargetkan Tumbuh 6,33 Persen Tahun Ini, (Online), (http://bisnis.liputan6.com/read/2484517/ industri-tekstil-ditargetkan-tumbuh-633persen-tahun-ini), diakses 7 Juni 2016.

Djumena, E. 2014. Industri Tekstil Vietnam Menyalip Indonesia, (Online), (http://bisniskeuangan. kompas.com/ read/ 2014/04/15/ 1856452/ Industri.Tekstil. Vietnam. Menyalip.Indonesia), diakses 7 Juni 2016.

\section{KESIMPULAN}

Berdasarkan hasil penelitian dapat disimpulkan bahwa: (1) Rasio kombinasi pelarut etanol 96\% dan air yang optimal untuk ekstraksi tannin dari daun sirsak adalah 1:1 dengan konsentrasi tannin yang dihasilkan sebesar 281,0 ppm per 1000 ppm larutan ekstrak; (2) Waktu ekstraksi yang optimal untuk ekstraksi tannin dari daun sirsak adalah 2 jam dengan konsentrasi tannin yang dihasilkan sebesar 281,0 ppm per 1000 ppm larutan ekstrak; (3) Bahan fiksasi yang menghasilkan ketahanan luntur warna yang optimal untuk pewarna alami daun sirsak adalah tawas. Pada uji pencucian, nilai Grey Scale (GS) akhir tawas adalah 3 (cukup) dan nilai Stanninng Scale (SS) akhir tawas adalah 4-5 (baik). Pada uji gosokan, nilai Stanninng Scale (SS) akhir tawas pada gosokan basah adalah 3-4 (cukup baik) dan nilai Stanninng Scale (SS) akhir tawas pada gosokan kering adalah 4-5 (baik); (4) Ekstrak daun sirsak dapat dimanfaatkan sebagai pewarna alami tekstil dengan ketahanan luntur warna yang baik serta ramah lingkungan.

Fitrihana, N. 2007. Teknik Eksplorasi Zat Pewarna Alam dari Tanaman Di Sekitar Kita untuk Pencelupan Bahan Tekstil. Jurnal Jurusan PKK FT UNY, 1-8.

Irianty, R.S. \& Verawati, R. 2012. Variasi Komposisi Pelarut Metanol-Air Pada Ekstraksi Daun Gambir (Uncaria gambir Roxb). Prosiding SNTK TOPI 2012, hlm. 248-251, Jurusan Teknik Kimia Fakultas Teknik Universitas Riau, Riau.

Kasmudjo, Probo, P., Widowati, T.B. 2011. Pemanfaatan Limbah Serbuk Kayu Mahoni sebagai Pewarna Alami Batik. Jurnal Teknologi Hutan Fakultas Kehutanan Universitas Gadjah Mada Yogyakarta, 381387.

Kusumaningsih, T., Asrilya, N.J., Wulandari, S., Wardani, D.R.T., \& Fatikhin, K. 2015. Pengurangan Kadar Tanin pada Ekstrak Stevia rebaudiana dengan Menggunakan Karbon Aktif. ALCHEMY Jurnal Penelitian Kimia, 11(1), 81-89. 
Kwartiningsih, E., Setyawardhani, D.A., Wiyatno, A., \& Triyono, A. 2009. Zat Warna Alami Tekstil. Ekuilibrium, 8(1), 41-47.

Lestari, P., Wijana, S., \& Putri, W.I. 2014. Ekstraksi Tanin dari Daun Alpukat (Persea Americana Mill.) sebagai Pewarna Alami (kajian proporsi pelarut dan waktu ekstraksi). Jurnal Jurusan Teknologi Industri Pertanian Fakultas Teknologi Pertanian Universitas Brawijaya Malang, 1-10.

Manurung R., Hasibuan R., \& Irvan. 2004. Perombakan Zat Warna Azo Reaktif Secara Anaerob dan Aerob. e-USU Repository, 1-19.

Mukhlis. 2011. Ekstraksi Zat Warna Alami Dari Kulit Batang Jamblang (Syzygium cumini) Sebagai Bahan Dasar Pewarna Tekstil. Jurnal Biologi Edukasi Progam Studi Pendidikan Biologi FKIP Unsyiah, 1-8.

Parasetia, D. E., Ritaningsih, \& Purwanto. 2012. Pengambilan zat warna alami dari kayu nangka. Jurnal Teknologi Kimia dan Industri, 1(1), 502-507.

Prayitno, R. E., Wijana, S., \& Diyah, B. S. 2014. Pengaruh Bahan Fiksasi Terhadap Ketahanan Luntur dan Intensitas Warna Kain Mori Batik Hasil Pewarnaan Daun Alpukat (Persea americana Mill.). Fakultas Teknologi Pertanian, Universitas Brawijaya.

Rosyida, A. \& Zulfiya, A. 2013. Pewarnaan Bahan Tekstil dengan Menggunakan Ekstrak Kayu Nangka dan Teknik Pewarnaannya untuk Mendapatkan Hasil yang Optimal. Jurnal Rekayasa Proses, 7(2), 54-58.
Saputro, A.N.C. 2012. Konsep Dasar Kimia Koordinasi. Yogyakarta: Deepublish.

Setyowati, W.A.E., Ariani, S.R.D., Ashadi, Mulyani, B., \& Rachmawati, C.P. 2014. Skrining Fitokimia dan Identifikasi Komponen Utama Ekstrak Metanol Kulit Durian (Durio zibethinus Murr.) Varietas Petruk. Seminar Nasional Kimia dan Pendidikan Kimia VI "Pemantapan Riset Kimia dan Asesmen dalam Pembelajaran Berbasis Pendekatan Saintifik", hlm. 271-280, Progam Studi Pendidikan Kimia Jurusan PMIPA FKIP UNS.

Sunarto. 2008. Teknologi Pencelupan dan Pencapan Jilid 3. Jakarta: Departemen Pendidikan Nasional.

Wilujeng, R.A., Kusnawati, \& Pratiwi, E. (2010). Ekstraksi dan Karakterisasi Zat Warna Alami dari Daun Mangga (Mangifera indica Liin) serta Uji Potensinya sebagai Pewarna Tekstil. Progam Kreativitas Mahasiswa-AI Tahun 2010, Hlm. 1-12. Universitas Negeri Malang, Malang.

Solomon-Wisdom, G., Ugoh, S., \& Mohammed, B. 2014. Phytochemical screening and antimicrobial activities of Annona muricata (L) leaf extract. American Journal Biology Chemistry Pharmaceutical Sciences, 2(1), 17. 